\title{
Pola Arus Perairan Kemujan, Karimunjawa Pada Musim Peralihan II dengan Menggunakan Model DELFT3D
}

\author{
Rahmat Yolansyah Putra*, Elis Indrayanti, Dwi Haryo Ismunarti, Gentur Handoyo, dan Aris Ismanto \\ Departemen Oseanografi, Fakultas Perikanan Dan Ilmu Kelautan, Universitas Diponegoro \\ Jl. Prof. H. Soedharto, SH, Tembalang Semarang. 50275 Telp/Fax (024) 7474698 \\ Email: *rahmatyolansyahputra@students.undip.ac.id
}

\begin{abstract}
Abstrak
Pulau Kemujan adalah salah satu dari 27 gugusan pulau pada Kepulauan Karimunjawa, Kabupaten Jepara yang ditetapkan sebagai zona pemanfaatan pengelolaan masyarakat sebagai kawasan budidaya. Arus adalah gerakan massa air umum yang terjadi di seluruh lautan, pola dari arus laut akan sangat mempengaruhi pola distribusi unsur hara, padatan tersuspensi dan parameter fisika dan kimia. Pemahaman mengenai pola arus penting bagi suatu perairan sehingga penelitian ini bertujuan untuk mengetahui pola arus Perairan Kemujan, Karimunjawa pada musim peralihan II dengan menggunakan model Delft3D. Modul hydrodynamic flow digunakan untuk memodelkan arah dan kecepatan arus laut, selanjutnya hasil dari model diverifikasi dengan data hasil pengukuran lapangan. Hasil penelitian menunjukkan bahwa pergerakan arus Perairan Kemujan, Karimunjawa pada musim peralihan II cenderung memiliki pola arus yang bergerak ke dua arah (bi-directional) dengan arah arus dominan yakni pada saat pasang mengarah ke timur dan pada saat surut mengarah ke barat. Kecepatan maksimum rata-rata pada kondisi pasang purnama (spring tide) pada bulan September memiliki nilai $0.0505 \mathrm{~m} / \mathrm{s}$, bulan Oktober $0.0526 \mathrm{~m} / \mathrm{s}$ dan bulan November $0.0564 \mathrm{~m} / \mathrm{s}$, dimana memiliki nilai yang lebih besar dibandingkan dengan kondisi pasang perbani (neap tide) yakni pada bulan September memiliki nilai $0.0475 \mathrm{~m} / \mathrm{s}$, bulan Oktober $0.0498 \mathrm{~m} / \mathrm{s}$ dan bulan November $0.0523 \mathrm{~m} / \mathrm{s}$. Arus yang terdapat pada perairan pulau Kemujan cenderung didominasi oleh arus pasang surut.
\end{abstract}

Kata kunci: Arus laut, Model Hidrodinamika, Delft3D, Pulau Kemujan

\begin{abstract}
Kemujan Island is one of the 27 clusters of islands in Karimunjawa Islands, Jepara Regency that are designated as utilization zones of community management as cultivation areas. Currents are water mass movement that occurs throughout the oceans, patterns of ocean currents will greatly affect the distribution patterns of nutrients, suspended solids, and physical and chemical parameters. Understanding current patterns are important, thus this study is to find out the current patterns of Kemujan Waters in the second transition season using Delft $3 D$ models. The hydrodynamic flow module is used to model the direction and speed of ocean currents, then the results of the model are verified with the data from field measurement. The results showed that the current movement in Kemujan Waters in the second transition season tends to have a bi-directional current pattern with the dominant current direction that is at high tide to the east and low tide to the west. The average maximum speed in spring tide conditions in September was $0.0505 \mathrm{~m} / \mathrm{s}$, October $0.0526 \mathrm{~m} / \mathrm{s}$, and November $0.0564 \mathrm{~m} / \mathrm{s}$, it has a greater value compared to neap tides in September at $0.0475 \mathrm{~m} / \mathrm{s}$, October at $0.0498 \mathrm{~m} / \mathrm{s}$, and November $0.0523 \mathrm{~m} / \mathrm{s}$. The currents in Kemujan Waters tend to be dominated by tidal currents.
\end{abstract}

Keyword: Sea Current, Hydrodynamic Model, Delft3D, Kemujan Island

\section{PENDAHULUAN}

Pulau Kemujan adalah bagian dari 27 gugusan pulau pada Kepulauan Karimunjawa yang merupakan kawasan penting berdasarkan fungsi dan manfaatnya sebagai Taman Nasional. Pulau Kemujan ditetapkan sebagai zona dari pemanfaatan pengelolaan masyarakat sebagai kawasan budidaya (Kartawijaya et al., 2004). 
Kepulauan Karimunjawa memiliki karakteristik geografis dan ekologis yang unik karena terletak di tengah lautan yaitu Laut Jawa namun dikelillingi pulau pulau kecil dan kawasan terumbu karang yang mengakibatkan kawasan ini dikategorikan ke dalam perairan semi tertutup (Yusuf et al., 2012). Hal ini mengakibatkan parameter hidrodinamika Perairan Karimunjawa memiliki karakteristik yang menarik untuk dikaji salah satunya adalah arus laut.

Beberapa penelitian tentang arus laut di Karimunjawa telah dilakukan diantaranya oleh BTNKJ (2017) yang menyatakan bahwa arus laut di Kepulauan karimunjawa dibangkitkan oleh pasang surut dengan arah pergerakan ke barat dan timur. Ismunarti et al., (2016) menyampaikan yakni besaran dari nilai parameter arus laut akan berkurang dengan bertambahnya kedalaman, dan kecepatan arus di permukaan laut adalah kecepatan arus tertinggi jika dibandingkan dengan profil kedalaman yang lain. Arus pasut maksimum di Perairan Kemujan diketahui terjadi ketika perpindahan fase pasang surut yakni ketika fase pasang ke surut lalu pada fase surut ke pasang ketika kondisi Spring tide (Indrayanti et al., 2021).

Pada penelitian ini kajian tentang arus laut di Perairan Kemujan, Karimunjawa dilakukan pada musim peralihan II dengan pendekatan hidrodinamika menggunakan model Delft3D. Kelebihan Delft3D yakni salah satunya memiliki area aplikasi perairan yang beragam dan kompleks dimana area aplikasi perairan yang Delft3D dapat simulasikan yakni terdiri dari arus, gelombang, pasang surut, densitas, tsunami, intrusi air laut, transport dari zat terlarut dan polutan (Deltares, 2011). Pendekatan model hidrodinamika dengan menggunakan software Delft3D-Flow diharapkan dapat memberikan gambaran detai tentang pola arus laut di perairan Pulau Kemujan, Karimunjawa sehingga mampu untuk diaplikasikan pada bidang kelautan dalam pemanfaatan dan pengelolaan.

\section{MATERI DAN METODE PENELITIAN \\ Area Penelitian}

Penelitian dilakukan di Perairan Kemujan, Karimunjawa dengan koordinat 5.78238990 LS, 110.461619957 BT (Gambar 1). Penelitian dilakukan pada musim peralihan II yaitu 1 September sampai dengan 30 November 2020.

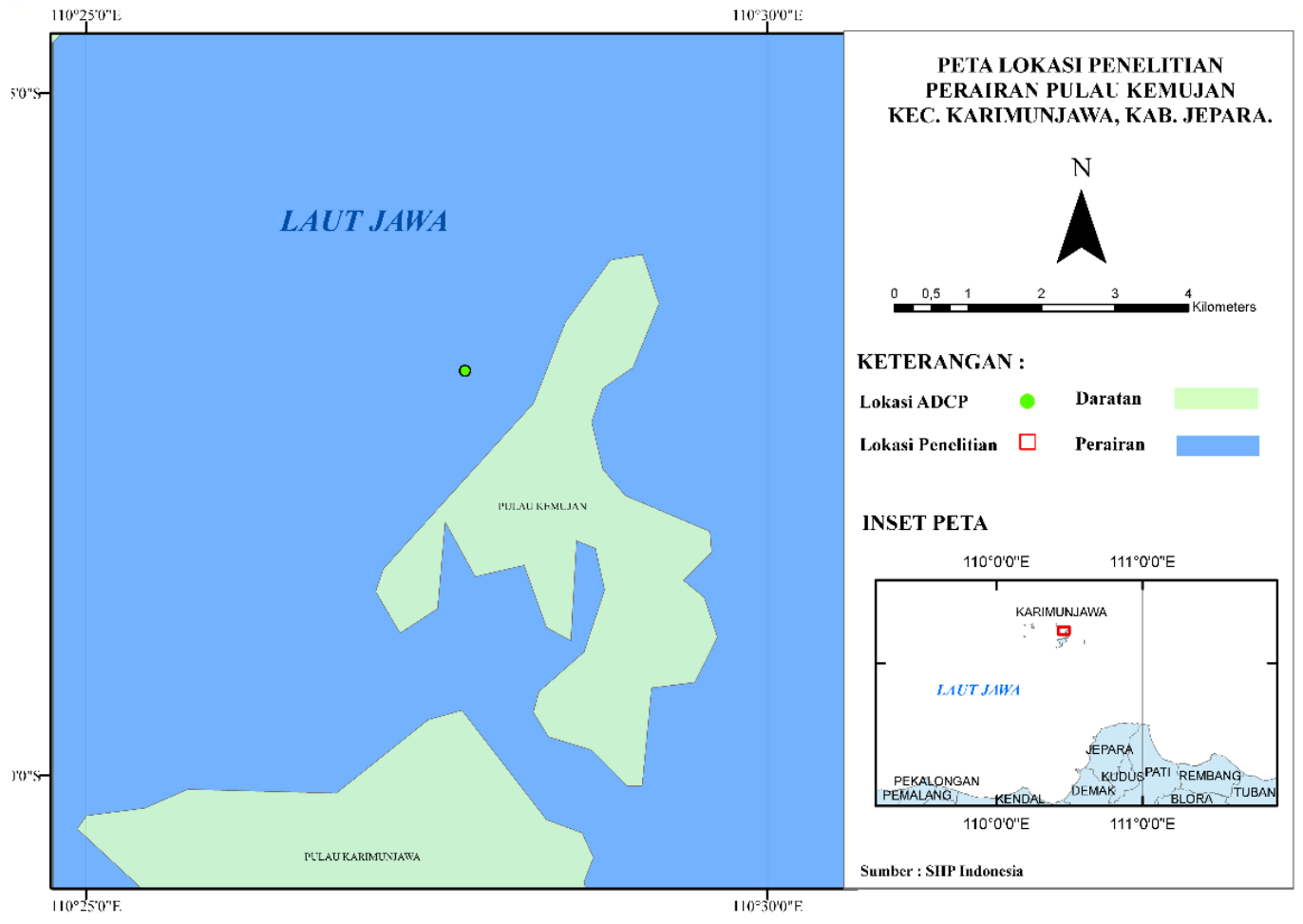

Gambar 1. Lokasi Penelitian 


\section{Materi Penelitian}

Penelitian ini menggunakan data yakni berupa data utama dan data pendukung. Variabel pembangkit model yang merupakan data pendukung terdiri dari data parameter pasang surut yang didapatkan dari data observasi Website Badan Informasi Geospasial (BIG) (http://tides.big.go.id/_diakses pada 25 Maret 2021) dan Website BWGeoHydromatics (https://info.bwgeohydromatics.com/txpo/ diakses pada 25 Maret 2021), data angin dari Website Copernicus ECMWF (https://cds.climate.copernicus.eu/ diakses pada 15 Mei 2021) dan data batimetri dari Website Batimetri Nasional Badan Inforamasi Geospasial (BIG) (DEMNAS (big.go.id) diakses pada 24 Maret 2021). Verifikasi hasil model digunakan data arus penelitian Indrayanti et al., (2021) sebagai data utama.

\section{Metode Penelitian}

Metode yang digunakan dalam penelitian ini adalah metode deskriptif untuk pengolahan data aliran dan metode pemodelan matematis untuk pemodelan dinamika fluida. Metode deskripsi ini digunakan untuk menggambarkan dan menjelaskan pola arus laut di perairan Pulau Kemujan. Metode ini dipilih karena ada beberapa faktor pembatas dalam penelitian ini yaitu waktu yang relatif singkat dan hanya jangka waktu tertentu. Metode permodelan menjadi sangat penting dalam mensimulasikan berbagai skenario seperti pola arus. Metode permodelan matematik juga telah banyak terbukti mampu untuk melakukan deskripsi suatu peristiwa dengan persamaan (Soewono et al., 2007).

\section{Pemodelan dengan Delft3d}

Simulasi ini dibuat dengan inputan yakni data batimetri perairan Pulau Kemujan, data ketinggian pasang surut, dan data angin pada program Delft3D-Flow. Domain model untuk simulasi ini memiliki dua syarat boundary yakni boundary tertutup dan boundary terbuka. Simulasi ini dilakukan dengan tujuan untuk menghasilkan model dari pola arus disebabkan oleh faktor pasang surut dan angin. Simulasi dilakukan pada 1 September 2020 sampai dengan 30 November 2020. Output dari pemodelan yang dilakukan adalah ketinggian muka air laut di titik verifikasi dan pola arus dari perairan pulau Kemujan, Karimunjawa.

Tabel 1. Setting dan parameter simulasi hidrodinamika

\begin{tabular}{ccc}
\hline No & Parameter & Keterangan \\
\hline 1 & Lama Simulasi & 91 hari \\
2 & Waktu Simulasi & 1 September -30 November 2020 \\
3 & Beda Jarak Sumbu & $25 \mathrm{~m}$ \\
4 & Luas Domain & $7.6 \mathrm{~km} \times 5.9 \mathrm{~km}$ \\
5 & Interval Simulasi & 30 menit \\
\hline
\end{tabular}

\section{Persamaan}

Persamaan pengatur untuk model Delft 3D dalam Delft3D-Flow User Manual (2014), terdiri atas persamaan kontinuitas dan persamaan momentum, didefinisikan sebagai berikut:

Persamaan Kontinuitas model Delft3D :

$$
\frac{\partial \zeta}{\partial t}+\frac{1}{\sqrt{G \xi \xi \sqrt{G \eta \eta}}} \frac{\partial[(d+\zeta)] U \sqrt{G \eta \eta}}{\partial \xi}+\frac{1}{\sqrt{G \xi \xi \sqrt{G \eta \eta}}} \frac{\partial[(d+\zeta)] V \sqrt{G \eta}}{\partial \eta}=(d+\zeta \zeta) Q
$$

dengan :

$$
\begin{aligned}
U=1 d+\zeta \int u d z \zeta d & =\int u d \sigma 0-1 \\
V=1 d+\zeta \int v d z \zeta d & =\int v d \sigma 0-1
\end{aligned}
$$

Persamaan Momentum model Delft3D

Sumbu $\xi$ 


$$
\frac{\partial u}{\partial t}+\frac{u}{\sqrt{G \xi \xi}} \frac{\partial u}{\partial \xi}-\frac{v}{\sqrt{G \eta \eta}}+\frac{\partial u}{\partial \eta}-\frac{v^{2}}{\sqrt{G \xi \xi \sqrt{G \eta \eta}}} \frac{\partial \sqrt{G \eta \eta}}{\partial \xi}+\frac{u v}{\sqrt{G \xi \xi \sqrt{G \eta \eta}}} \frac{\partial \sqrt{G \xi \xi}}{\partial \eta}-f v=-\frac{1}{\rho o \sqrt{G \xi \xi}} P \xi+F \xi+\frac{1}{(d+\zeta)^{2}} \frac{\partial}{\partial \sigma}\left(u V \frac{\partial u}{\partial \sigma}\right)+M \xi
$$

Sumbu $\eta$

$$
\frac{\partial v}{\partial t}+\frac{u}{\sqrt{G \xi \xi}} \frac{\partial u}{\partial \xi}-\frac{v}{\sqrt{G \eta \eta}}+\frac{\partial v}{\partial \eta}-\frac{u^{2}}{\sqrt{G \xi \xi \sqrt{G \eta \eta}}} \frac{\partial \sqrt{G \xi \xi}}{\partial \eta}+\frac{u v}{\sqrt{G \xi \xi \sqrt{G \eta \eta}}} \frac{\partial \sqrt{G \eta \eta}}{\partial \xi}-f u=-\frac{1}{\rho o \sqrt{G \xi \xi}} P \eta+F \eta+\frac{1}{(d+\zeta)^{2}} \frac{\partial}{\partial \sigma}\left(u V \frac{\partial v}{\partial \sigma}\right)+M_{\eta}
$$

\section{Domain Model}

Domain model arus dengan panjang grid pada Delft3D dijelaskan dengan variabel $\mathrm{M}$ dan $\mathrm{N}$, dengan $\mathrm{M}$ searah sumbu $\mathrm{x}$ dan $\mathrm{N}$ searah sumbu y. Pada simulasi ini, domain model (Gambar 2) yang dibuat memiliki panjang $\mathrm{m}$ sebesar 7,6 km dan panjang $\mathrm{n}$ sebesar 5,9 km dengan titik nol berada pada ujung model (timur laut)

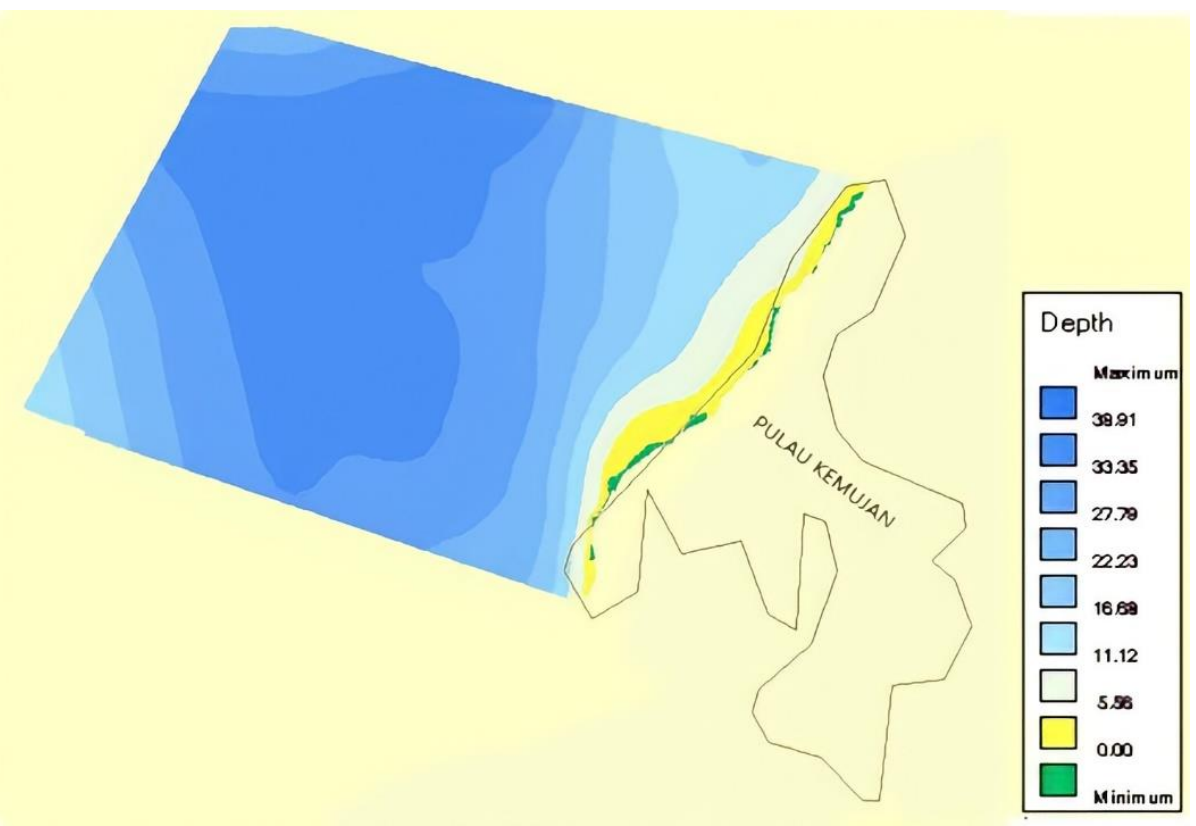

Gambar 2. Domain Model

Batimetri yang memiliki kedalaman paling besar ditandai dengan warna biru tua dimana memiliki nilai kedalaman sebesar 39,9 m dan batimetri yang memiliki kedalaman paling kecil ditandai dengan warna kuning putih dimana memiliki nilai kedalaman sebesar $0-5$ meter. Domain model ini memiliki dua syarat boundary yakni boundary tertutup dan boundary terbuka. Kondisi boundary terbuka yakni terdiri dari batas utara, batas barat dan batas selatan sedangkan batas tertutup yakni garis pantai berada pada bagian timur dari domain model. Titik observasi pada model yakni adalah titik observasi ADCP yang berada pada titik (M: 73, N: 238) atau berada pada koordinat (Y: $-5.78238990, \mathrm{X}$ : 110.461619957) yang tujuan dari titik observasi ini adalah untuk melihat dan melakukan perbandingan antara data arus hasil model dengan data arus yang diperoleh dari hasil pengukuran lapangan menggunakan ADCP pada lokasi tersebut.

\section{Verifikasi Model}

Bedasarkan Septiawan dan Astuti (2016), nilai Root Mean Square Error merupakan rataan dari tingkat error pada data sampel, dimana rumusnya adalah : 


$$
\text { Root Mean Square Error }=\frac{\sqrt{\frac{\sum_{i=1}^{n}(y i-\hat{y})^{\wedge} 2}{n}}}{n}
$$

Dengan n, yi, ŷi merupakan jumlah suatu data, data observasi dan data model. Tingkat kualitas model dan kesesuaian yang berdasarkan Tabel 2 berikut :

Tabel 2. Interpretasi nilai Root Mean Square Error

\begin{tabular}{cc}
\hline RMSE & Tingkat kesalahan \\
\hline $0-0.29 \%$ & Rendah \\
\hline $0.3-0.59 \%$ & Sedang \\
\hline $0.6-0.89 \%$ & Tinggi \\
\hline$>0.90 \%$ & Sangat Tinggi \\
\hline
\end{tabular}

\section{HASIL DAN PEMBAHASAN}

Pola Angin (Windrose)

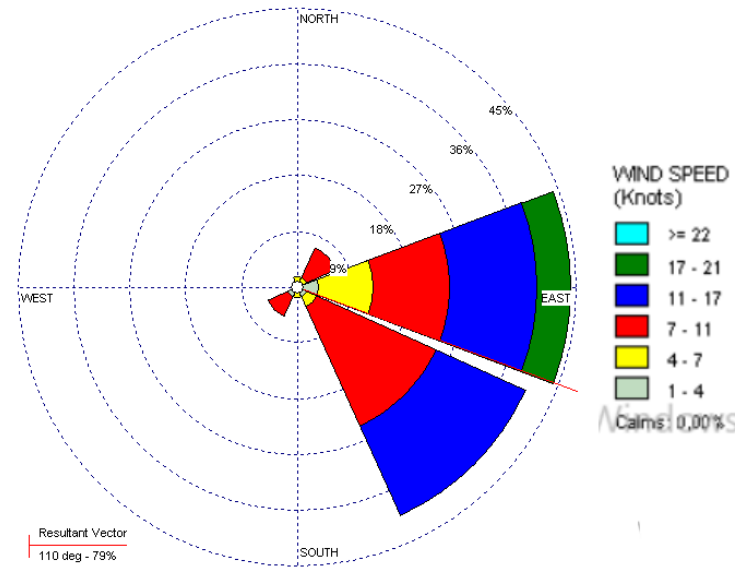

(a)

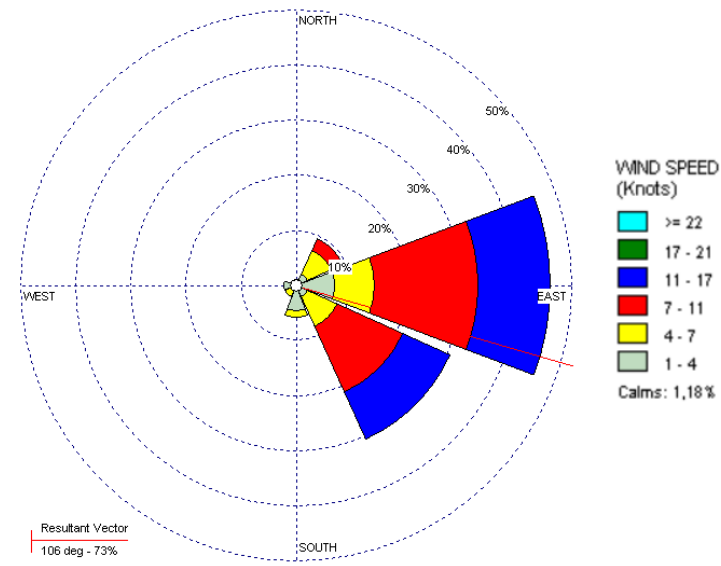

(b)



(c)

Gambar 3. Windrose (a) September, (b) Oktober, (c) November

Gambar 3 merupakan windrose pada musim peralihan dua di setiap bulannya yakni Bulan September, Oktober dan November. Pada September, pola angin cenderung mengarah pada arah timur dan tenggara. Distribusi frekuensi dari klasifikasi angin dominan yakni pada kecepatan angin sebesar 17-21 knots dengan 
dominasi sebesar 42\% mengarah ke timur dan kecepatan 11-17 knots dengan dominasi sebesar 30\% yang mengarah ke tenggara. Pada bulan Oktober, pola angin juga cenderung dominan mengarah ke timur dan tenggara. Distribusi dari frekuensi dari klasifikasi angin dominan yakni pada kecepatan angin sebesar 11-17 knots dengan dominasi sebesar 34\% mengarah ke timur dan tenggara. Pada bulan November, pola angin terlihat sangat dominan mengarah ke timur dan sebagian kecil lainnya mengarah ke tenggara dan barat daya. Distribusi dari frekuensi dari klasifikasi angin dominan yakni pada kecepatan angin sebesar 11-17 knots dengan dominasi sebesar 35\% mengarah ke timur.

\section{Verifikasi Model}

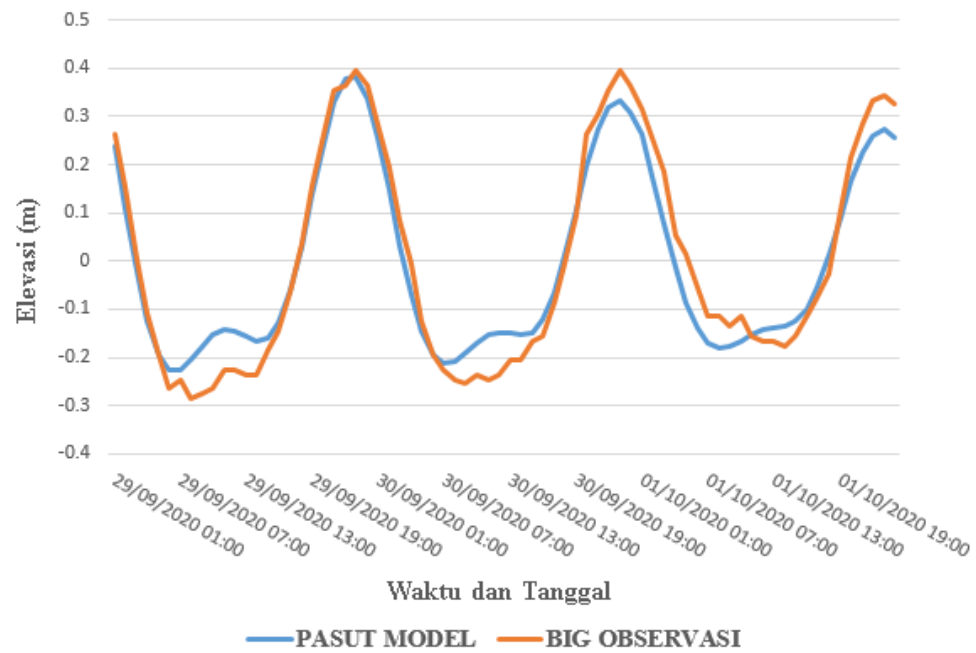

Gambar 4. Perbandingan Ketinggian Muka Air Laut Hasil Pemodelan VS Hasil Observasi (BIG)

Data ketinggian muka air laut yang dimodelkan (Gambar 4) konsisten dengan data ketinggian muka air laut yang diamati oleh Badan Informasi Geospasial, terlihat bahwa pola pasang surut antara keduanya adalah sama, yaitu tipe pasang harian tunggal. Hasil penelitian menunjukkan bahwa besaran dan fase ketinggian muka air laut yang disimulasikan telah mewakili nilai ketinggian muka air laut hasil observasi lapangan. Selain itu didapatkan nilai RMSE sebesar 6,45\%. Dari hasil yang diperoleh dapat diketahui bahwa error data model sangat kecil. Karena mengacu pada penggunaan Tabel 2 maka dapat disimpulkan bahwa muka air laut ketinggian hasil model telah menggambarkan kondisi perairan yang sebenarnya pada perairan Kemujan, KarimunJawa

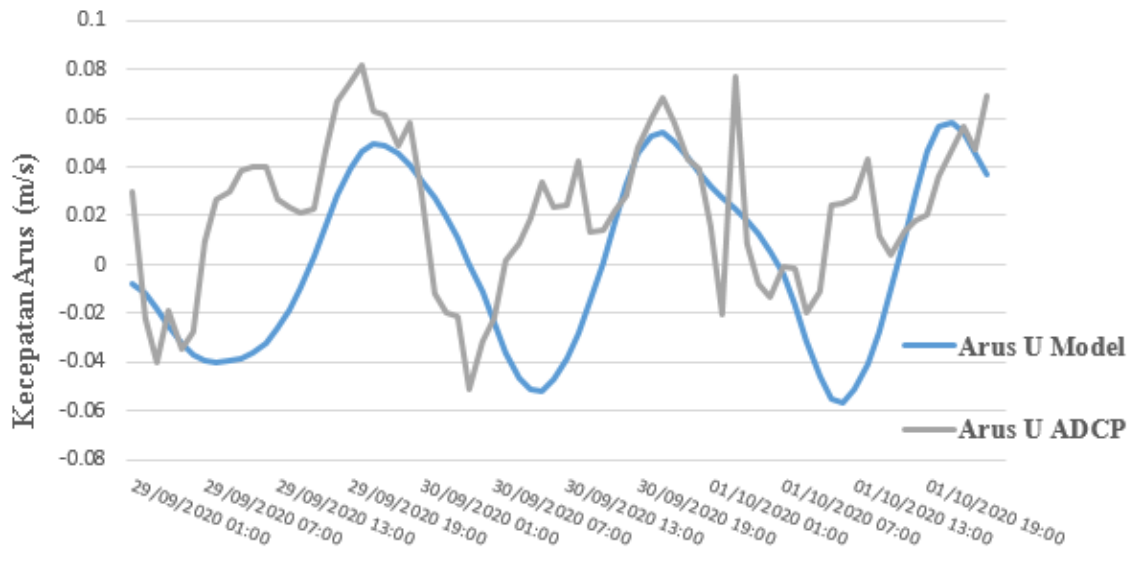

Tanggal dan Waktu

Gambar 5. Perbandingan Nilai Kecepatan dalam Arah U Hasil Pemodelan VS Observasi Indrayanti et al.,(2021) 


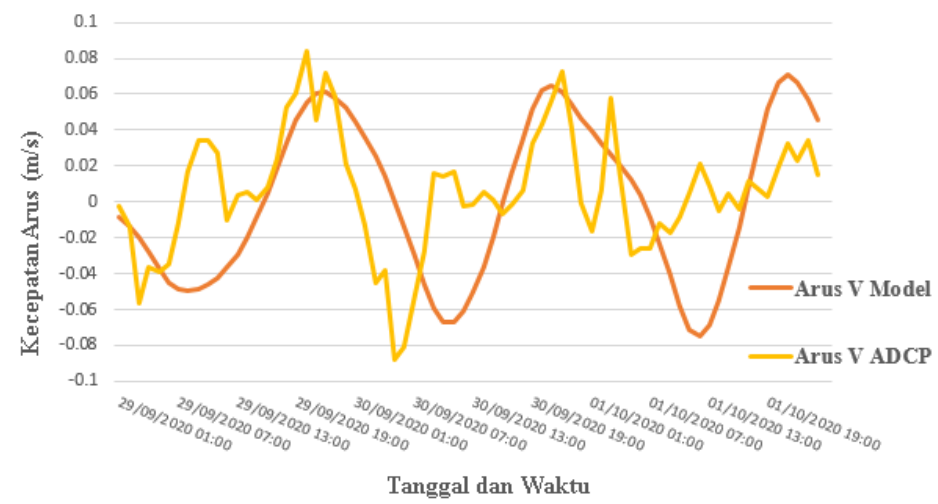

Gambar 6. Perbandingan Nilai Kecepatan dalam Arah V Hasil Pemodelan VS Observasi Indrayanti etal.,(2021)

Pada hasil pemodelan dalam komponen kecepatan $u$ dan $v$ didapatkan kecepatan arus maksimum adalah benilai $0.058 \mathrm{~m} / \mathrm{s}$ dan $0.071 \mathrm{~m} / \mathrm{s}$ sedangkan pada hasil data pengukuran lapangan ADCP (Indrayanti et al., 2021) diperoleh nilai $u$ dan $v$ bernilai $0.081 \mathrm{~m} / \mathrm{s}$ dan $0.084 \mathrm{~m} / \mathrm{s}$. Pola kecepatan arus dari hasil pemodelan dan data lapangan terlihat dalam (Gambar 5) dan (Gambar 6). Berdasarkan gambar tersebut dapat terlihat bahwa terdapat suatu kemiripian/kesesuaian dari pola arus hasil pemodelan dengan hasil observasi lapangan di perairan pulau Kemujan, Karimunjawa. Nilai RMSE yang didapatkan komponen $u$ dari perbandingan hasil pemodelan dan data lapangan yakni bernilai $4.07 \%$. Sedangkan nilai RMSE yang didapatkan komponen $v$ dari perbandingan hasil pemodelan dan data lapangan yakni bernilai $4.30 \%$.

Selain membandingkan kecepatan arus komponen $u$ dan $v$, dilakukan juga pembuatan grafik kecepatan total (speed) (Gambar 7) dari kecepatan arus hasil pemodelan dan hasil penelitian Indrayanti et al., (2021) yang menunjukkan nilai kecepatan arus maksimun yaitu $0.0938 \mathrm{~m} / \mathrm{s}$. Selain itu nilai dari Root mean square error yang rendah yakni 3.2\% mengindikasikan jika tingkat error dari data yang rendah. Pola kecepatan arus permodelan hidrodinamika sudah menggambarkan pola kecepatan arus observasi penelitian Indrayanti etal., (2021).

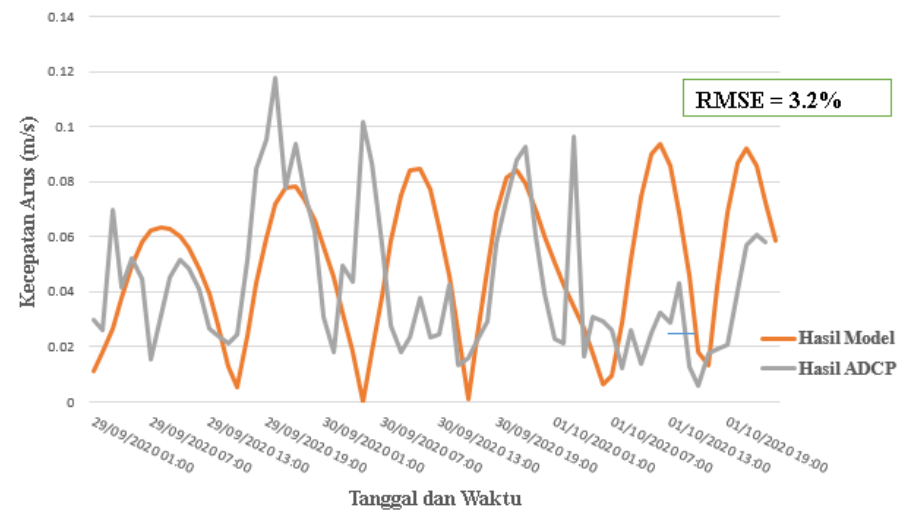

Gambar 7. Perbandingan Kecepatan Arus Total Data Hasil Pemodelan vs Data Lapangan Indrayanti etal.,(2021)

\section{Hasil Model Arus}

Hasil model yang diperoleh berupa kondisi arus ketika fase pasang purnama (Spring tide) dan pasang perbani (Neap tide). Tiap kondisi dari hasil model hidrodinamika terbagi menjadi 4 bagian yaitu pola arus saat surut, pola dari arus ketika surut ke pasang, pola dari arus ketika pasang dan pola arus ketika pasang ke surut. Hasil model hidrodinamika dari pola arus terlihat pada (Gambar 8) sampai (Gambar 14). Pola arus yang terdapat 
dalam musim peralihan 2 memiliki kecenderungan yang sama pada setiap bulannya. Pola arus pada bulan September, Oktober dan November memiliki dua arah dari arus yang ada atau disebut dengan arus tipe $b i$ directional. Pola arus yakni ke arah barat (lautan) dalam kondisi surut dan surut ke pasang bergerak sedangkan pola arus yakni ke arah timur (pantai) dalam kondisi pasang dan pasang ke surut.

\section{Pasang Purnama (Spring tide)}

\section{Bulan September}
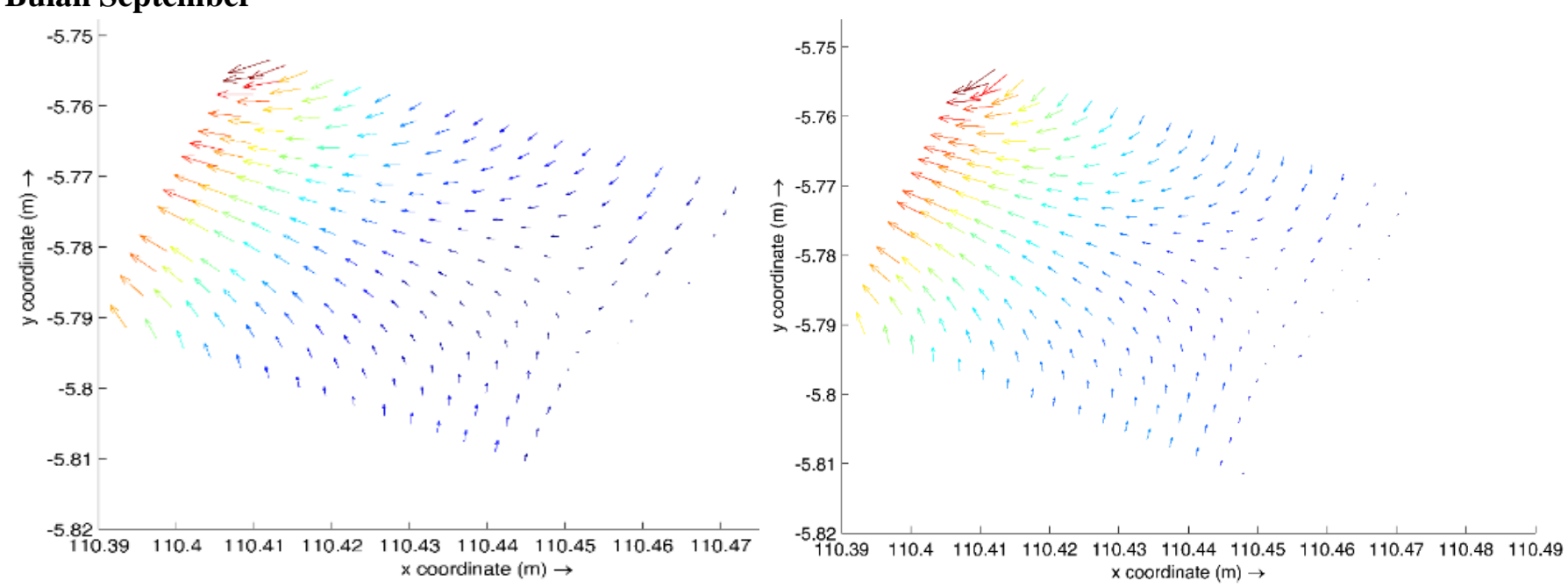

(a)

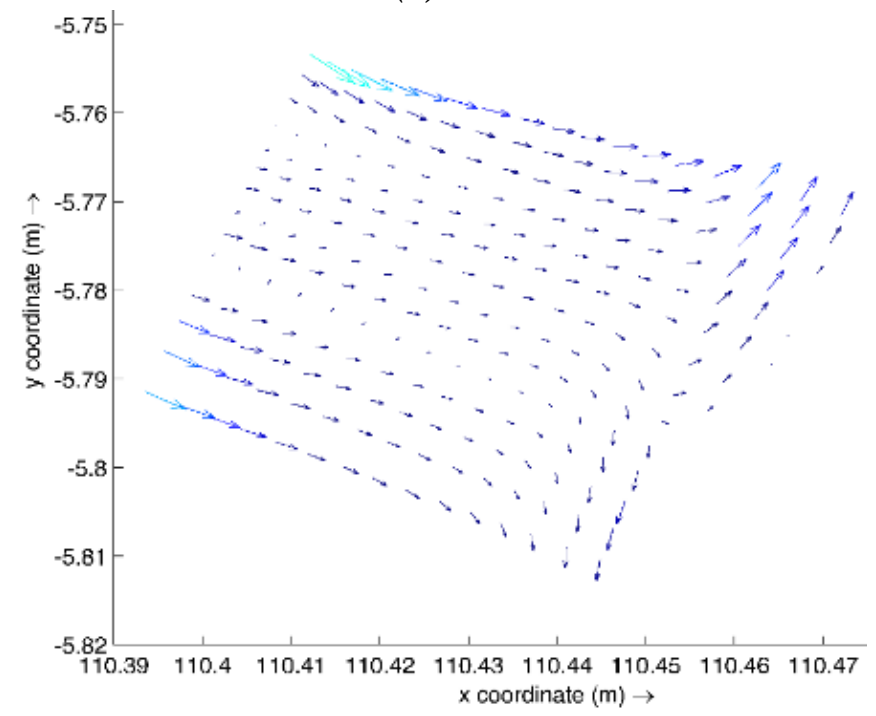

(c)

(b)

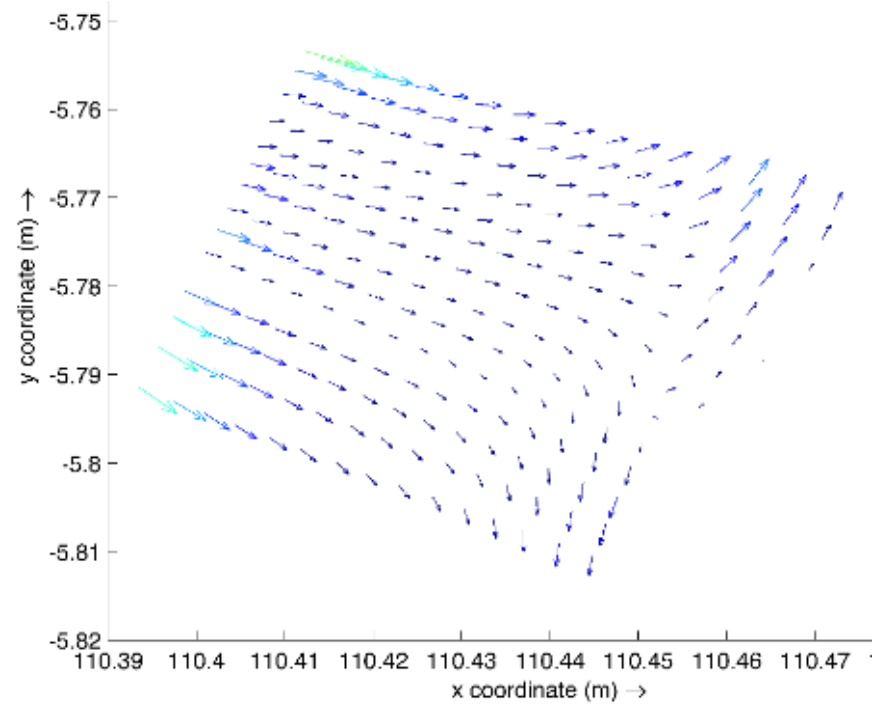

(d)

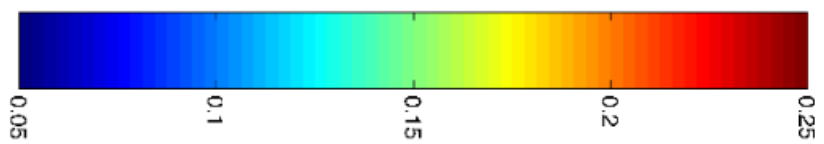

Gambar 8. Pola dari Arus September (Spring tide) (a) Surut (b) Surut ke Pasang (c) Pasang (d) Pasang ke Surut 


\section{Bulan Oktober}

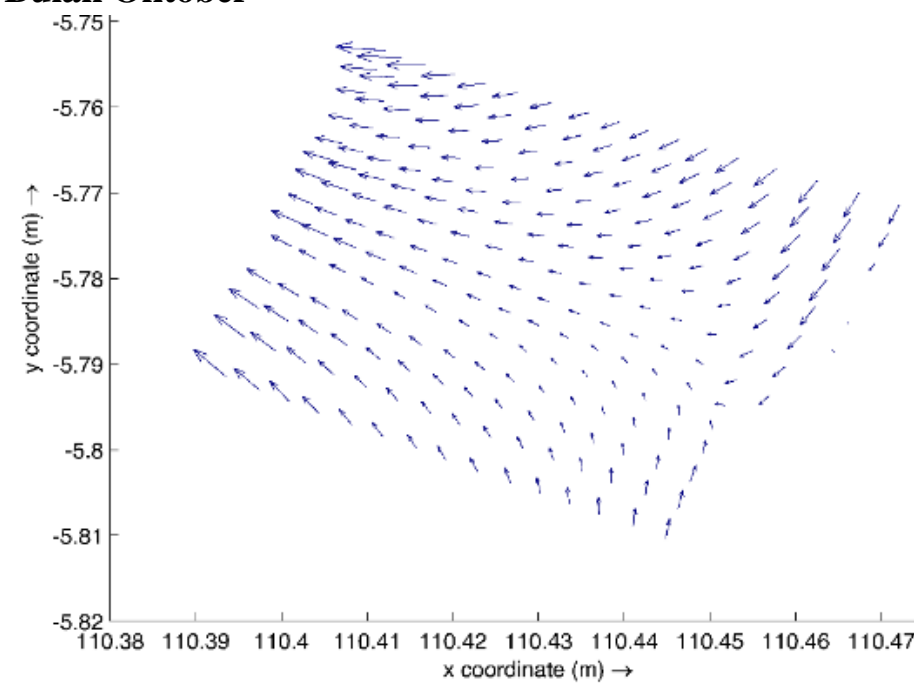

(a)

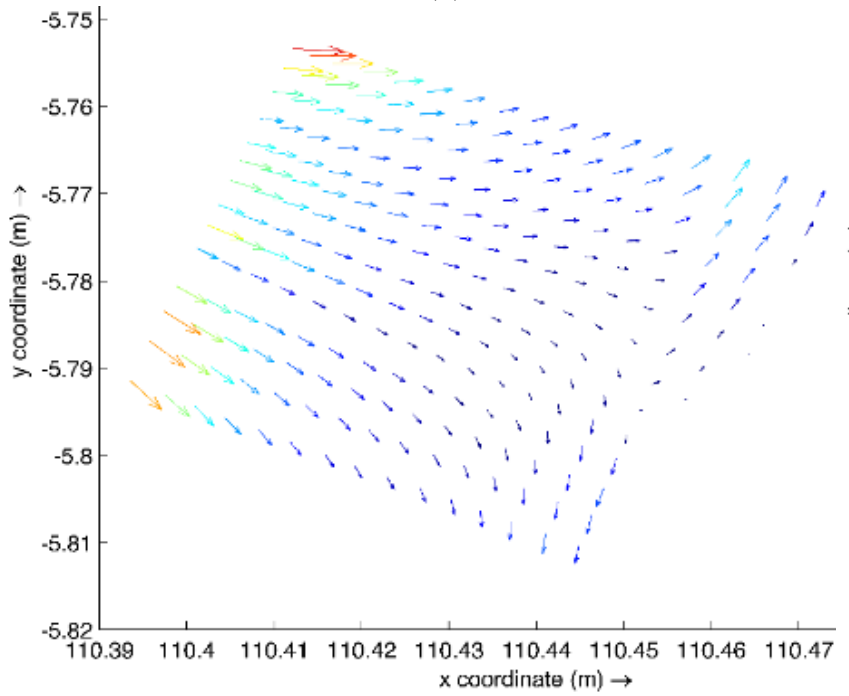

(c)

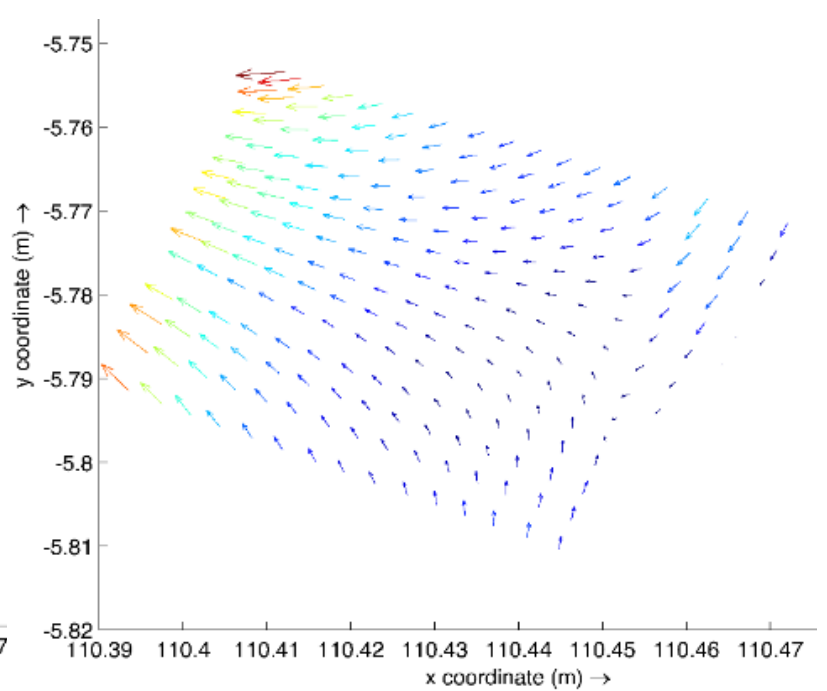

(b)

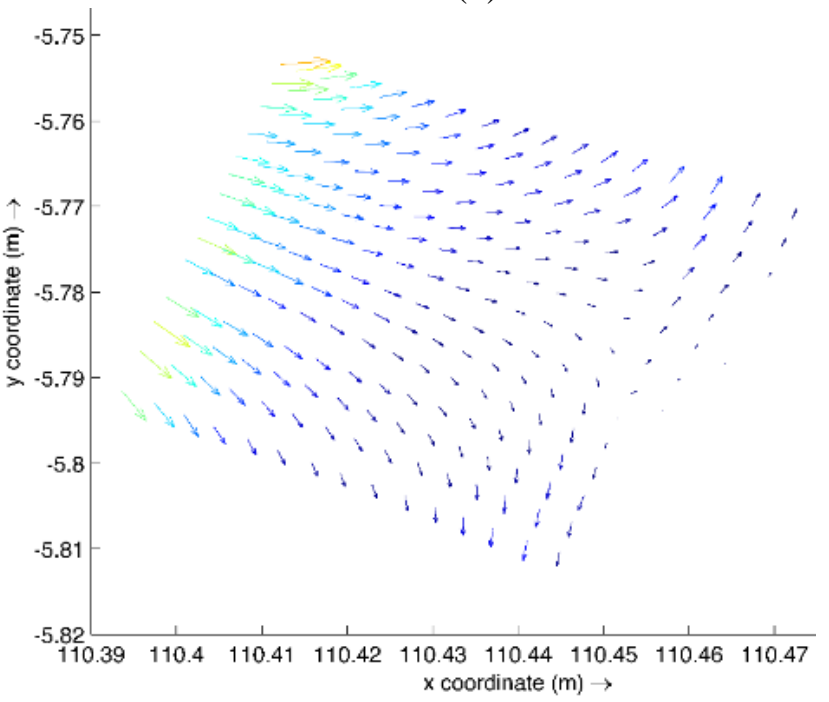

(d)

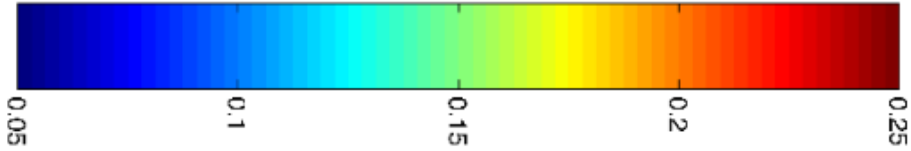

Gambar 9. Pola dari Arus Oktober (Spring tide) (a) Surut (b) Surut ke Pasang (c) Pasang (d) Pasang ke Surut 


\section{Bulan November}

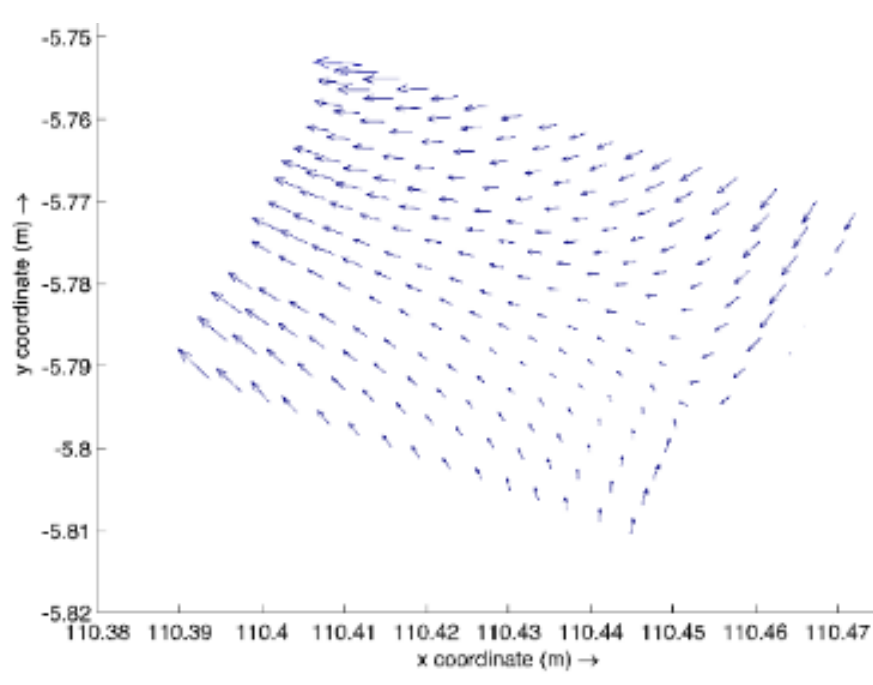

(a)

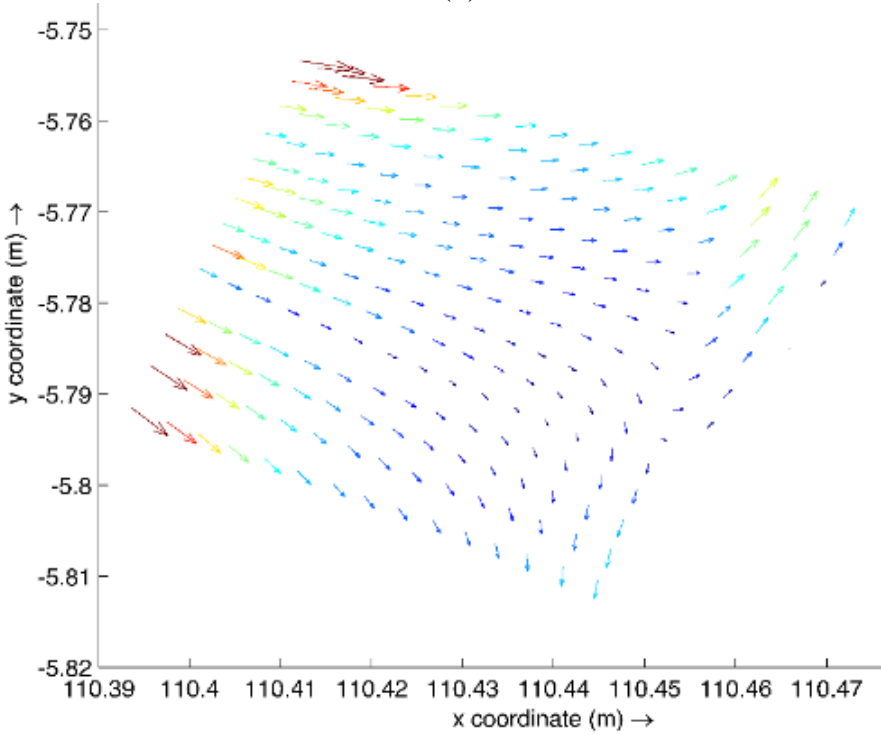

(c)

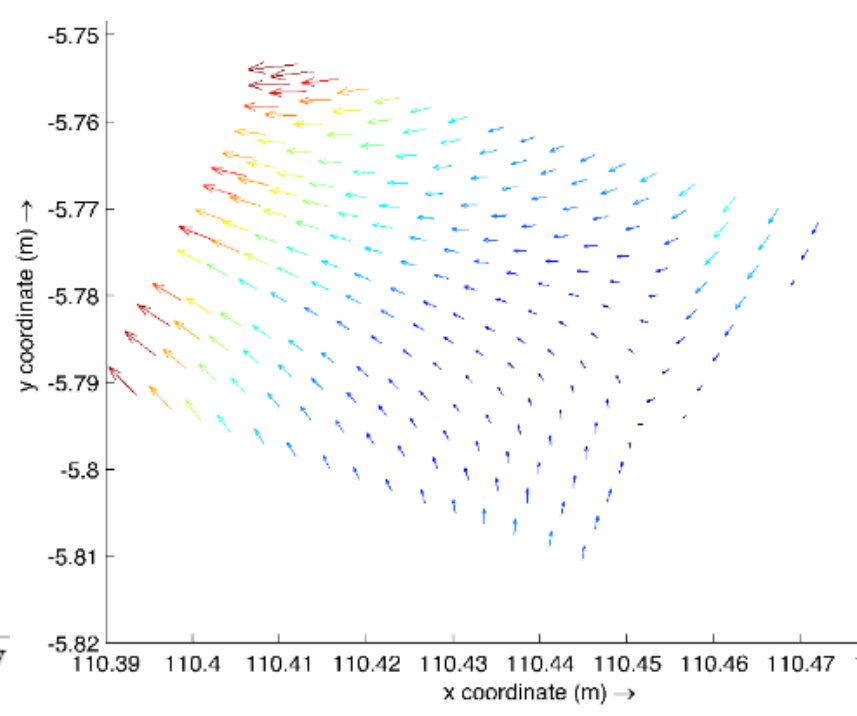

(b)

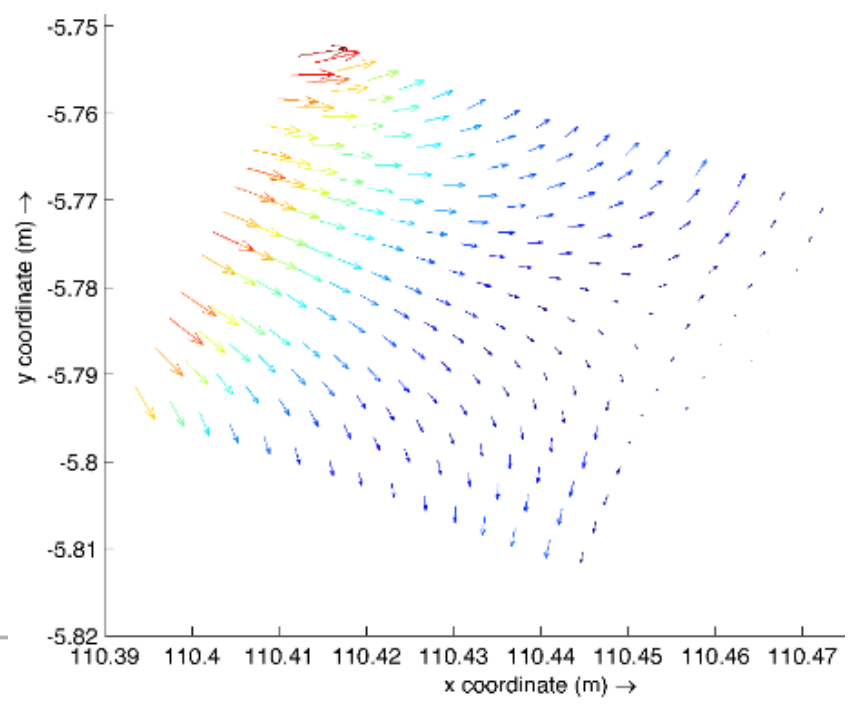

(d)

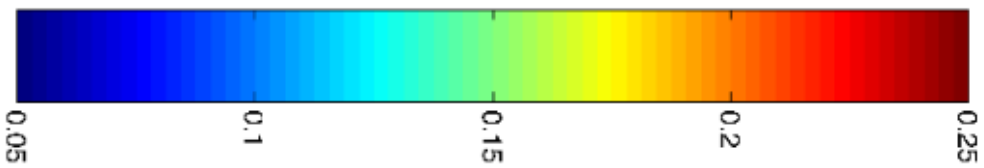

Gambar 11. Pola dari Arus November (Spring tide) (a) Surut (b) Surut ke Pasang (c) Pasang (d) Pasang ke Surut 


\section{Pasang Perbani (Spring tide)}

\section{Bulan September}
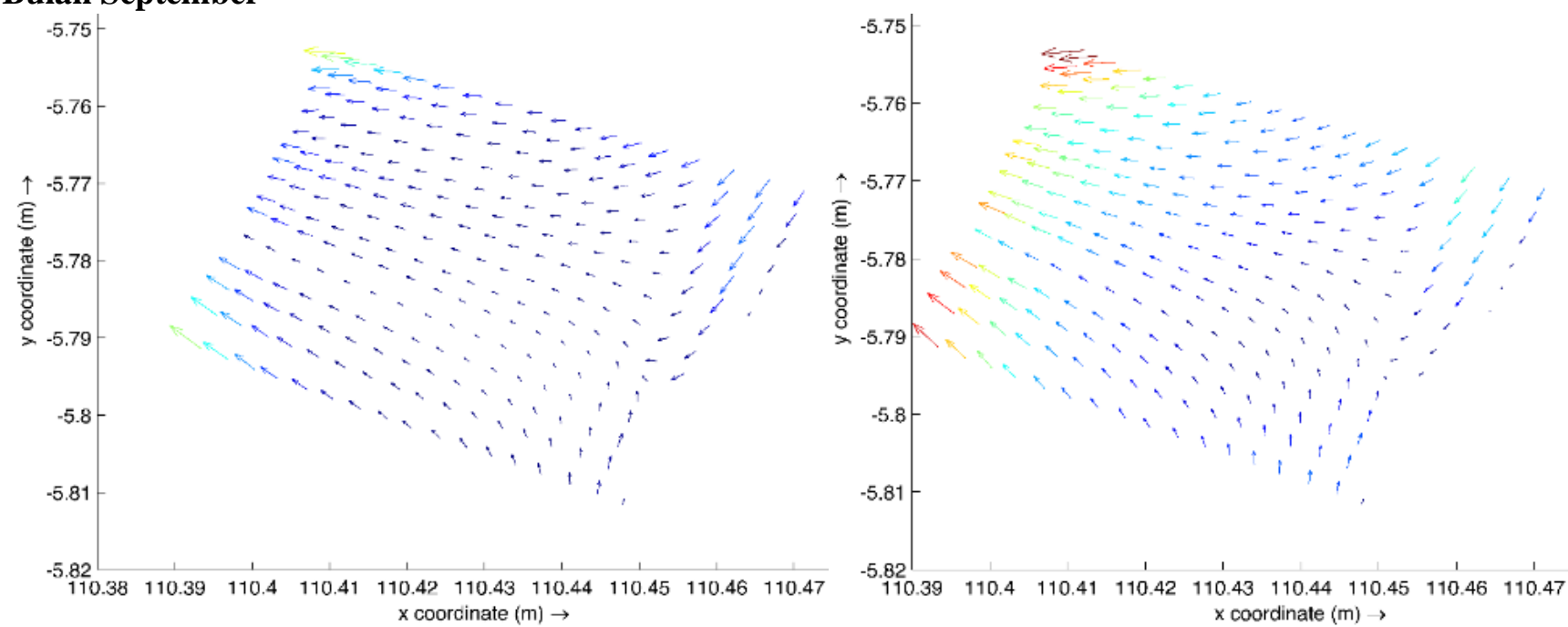

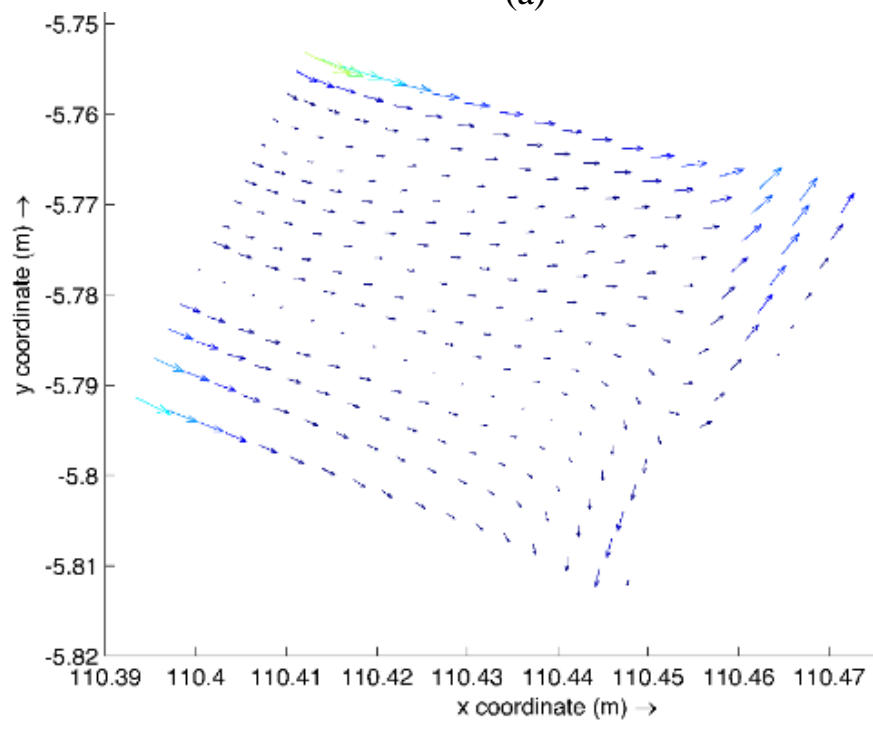

(c) (b)

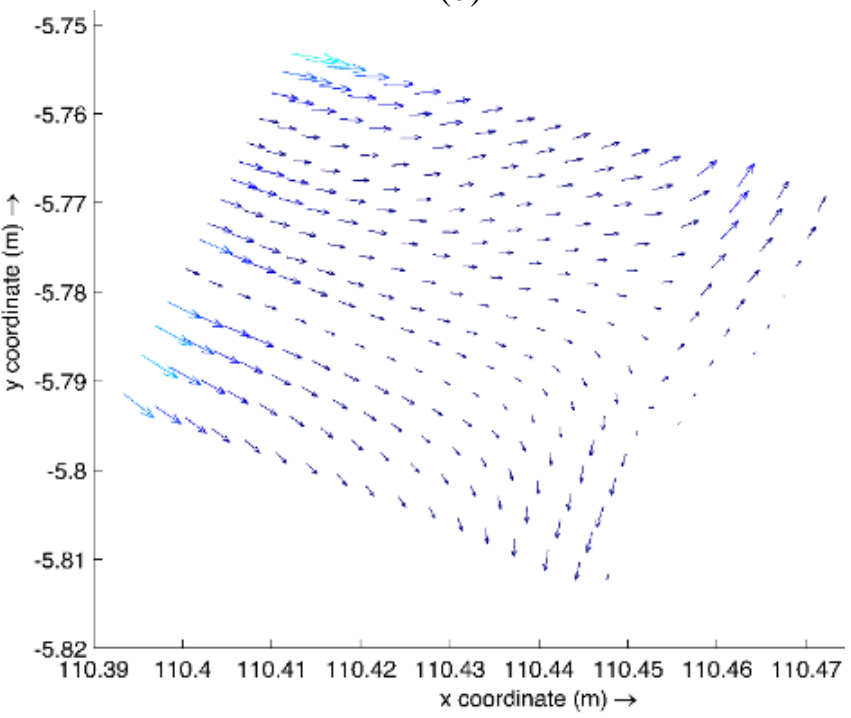

(d)

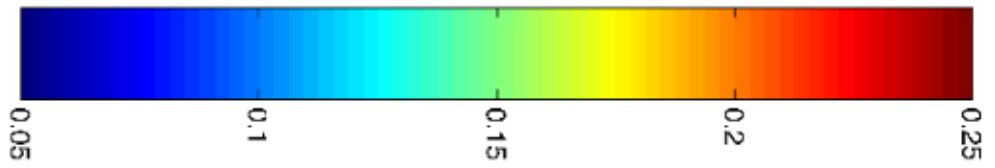

Gambar 12. Pola dari Arus September (Neap tide) (a) Surut (b) Surut ke Pasang (c) Pasang (d) Pasang ke Surut 


\section{Bulan Oktober}

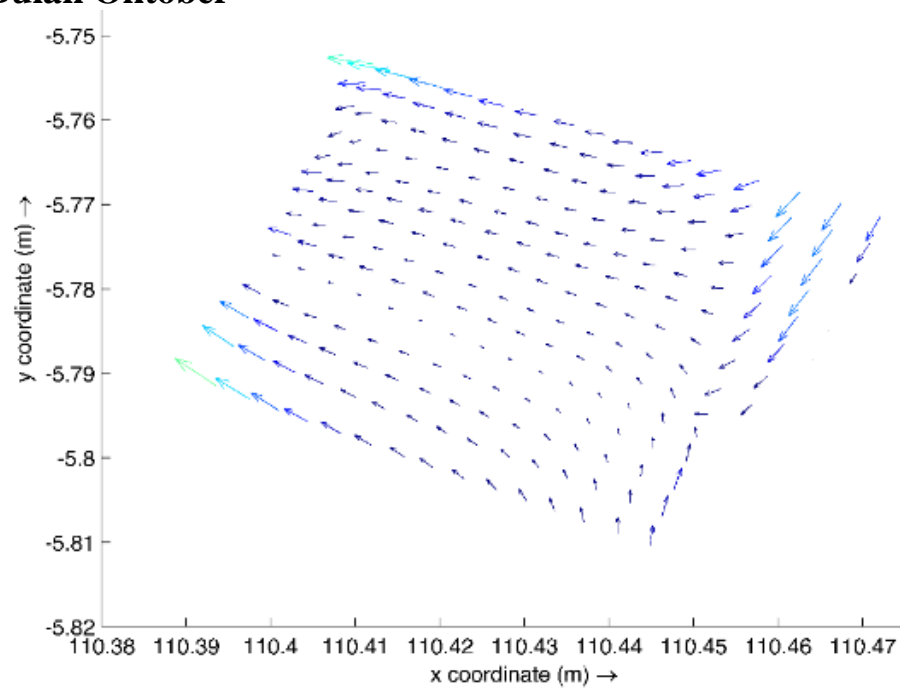

(a)

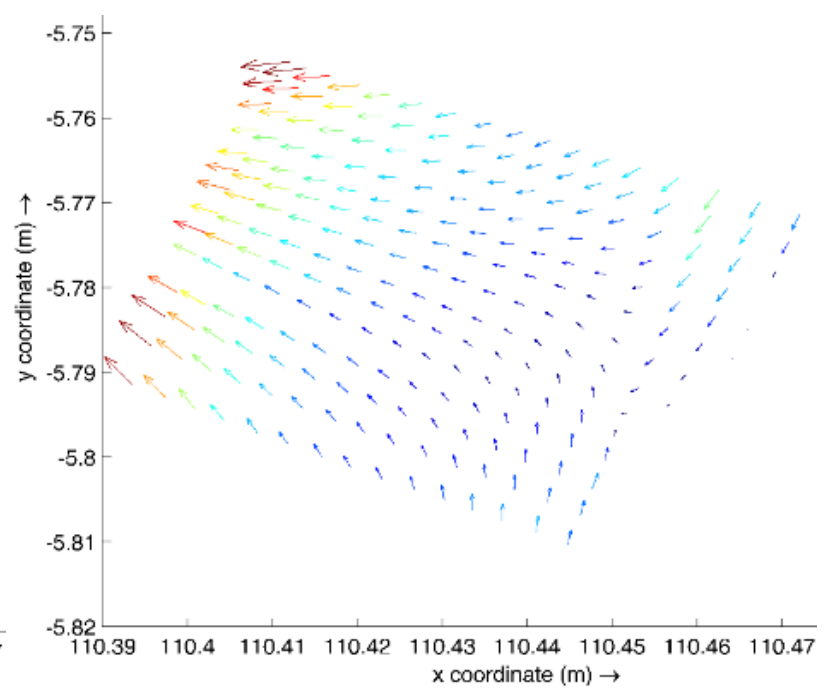

(b)

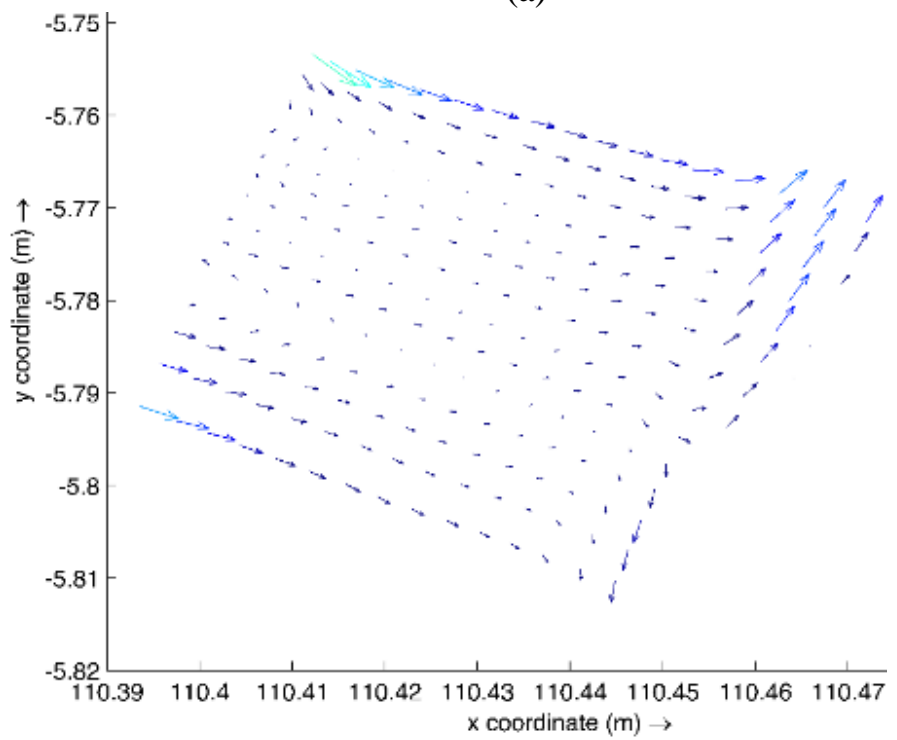

(c)

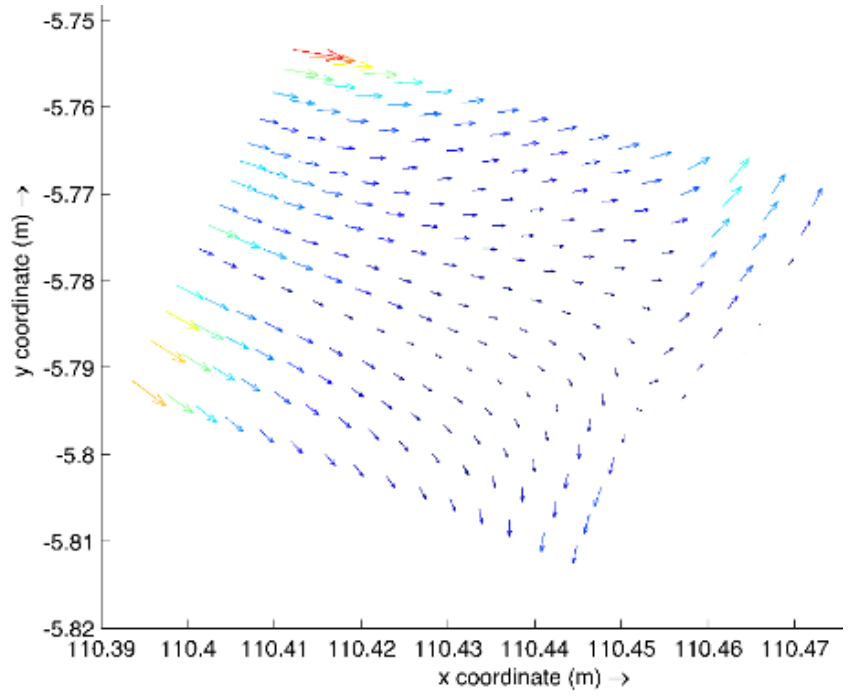

(d)

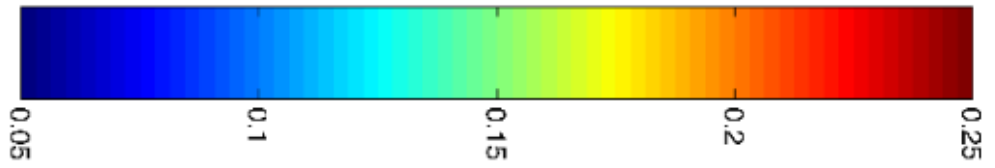

Gambar 13. Pola dari Arus Oktober (Neap tide) (a) Surut (b) Surut ke Pasang (c) Pasang (d) Pasang ke Surut 


\section{Bulan November}

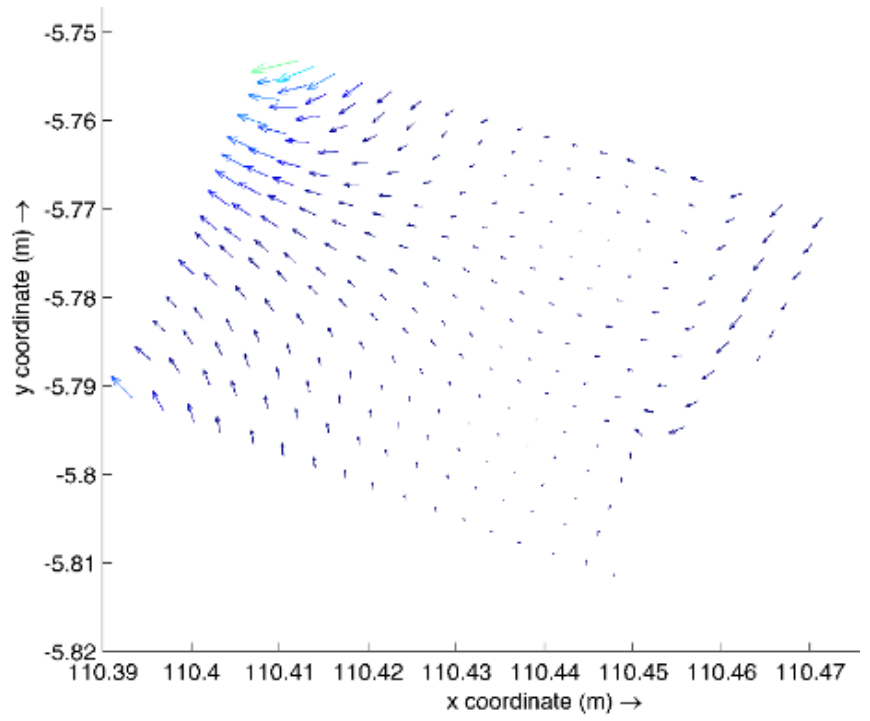

(a)

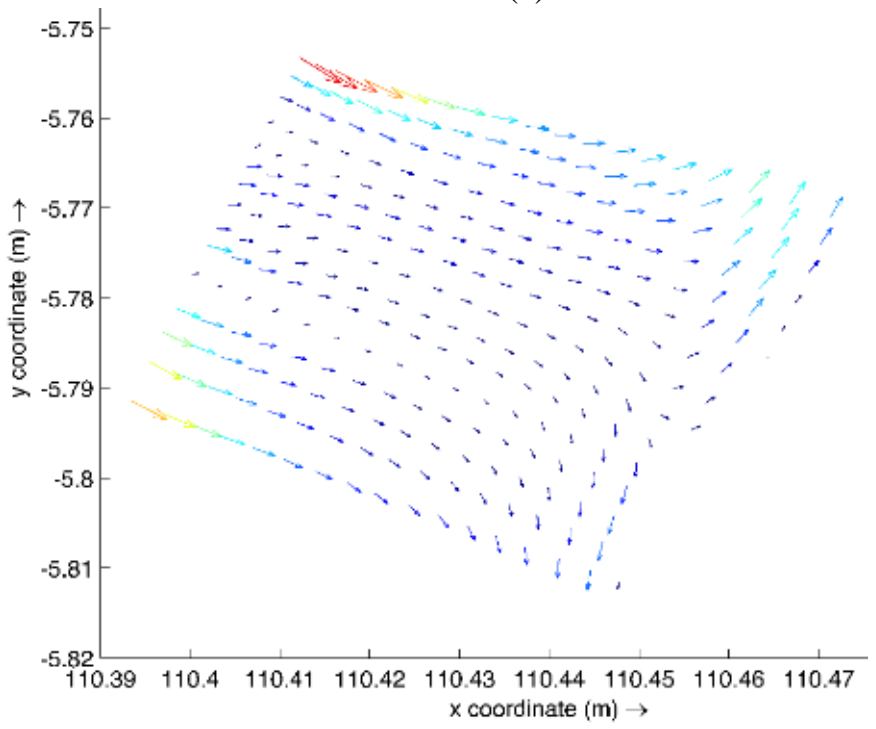

(c)

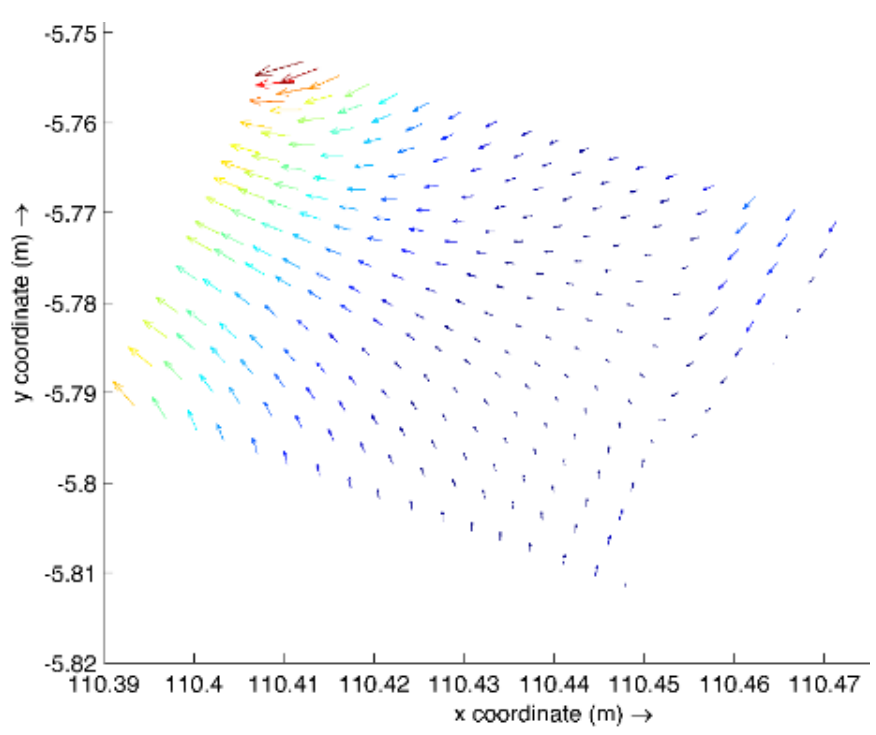

(b)

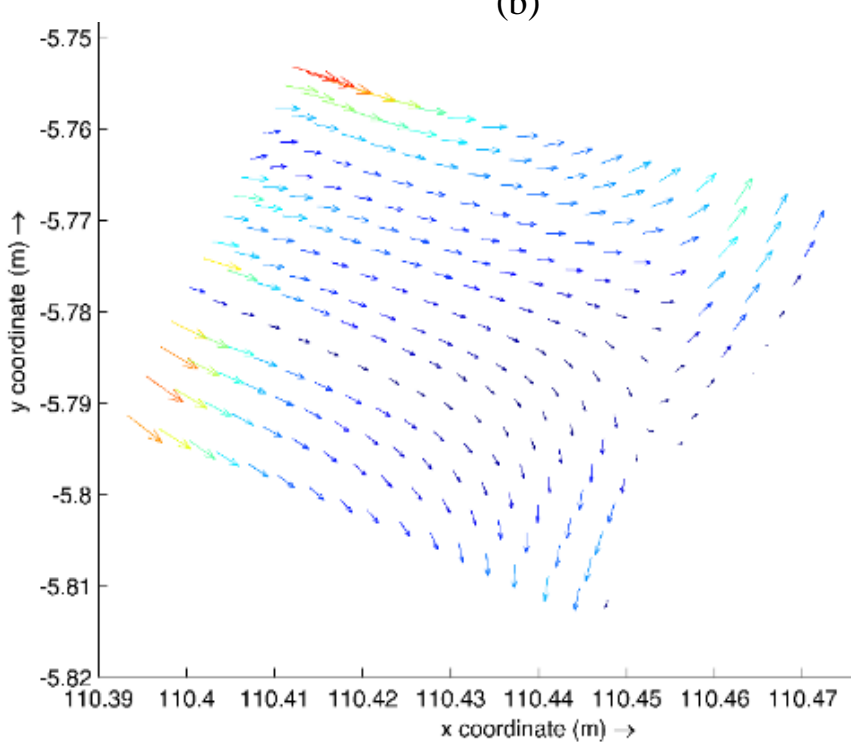

(d)

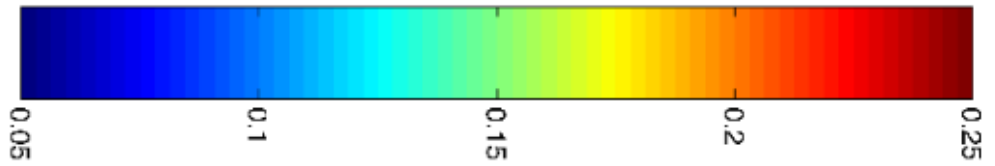

Gambar 14. Pola dari Arus November (Neap tide) (a) Surut (b) Surut ke Pasang (c) Pasang (d) Pasang ke Surut

Kecepatan yang terdapat pada perairan pulau Kemujan, Karimunjawa pada kondisi pasang purnama (Spring tide) dalam September memiliki nilai $0.0505 \mathrm{~m} / \mathrm{s}$, Oktober $0.0526 \mathrm{~m} / \mathrm{s}$ dan bulan November $0.0564 \mathrm{~m} / \mathrm{s}$ sedangkan kondisi pasang perbani (Neap tide) yakni September memiliki nilai $0.0475 \mathrm{~m} / \mathrm{s}$, bulan Oktober 0.0498 $\mathrm{m} / \mathrm{s}$ dan November $0.0523 \mathrm{~m} / \mathrm{s}$. 
Tabel 3. Tabel Perbandingan Kecepatan Arus

\begin{tabular}{ccccc}
\hline Waktu & Kondisi & Kecepatan Arus & Min & \multirow{2}{*}{ Maks } \\
\hline \multirow{2}{*}{ September } & Purnama & 0.0505 & 0.0475 & 0.0505 \\
& Perbani & 0.0475 & & \\
\hline \multirow{2}{*}{ Oktober } & Purnama & 0.0526 & 0.0498 & 0.0526 \\
& Perbani & 0.0498 & & \\
\hline \multirow{2}{*}{ November } & Purnama & 0.0564 & \multirow{2}{*}{0.0523} & 0.0564 \\
\hline
\end{tabular}

\section{PEMBAHASAN}

Pada domain model yang telah dibuat terlihat bahwa pada perairan Pulau Kemujan memiliki nilai kedalaman yakni dari 0 meter - 39meter dimana kedalaman 0 meter disimbolkan oleh warna kuning dan kedalaman 39 meter berwarna biru tua. Terlihat bahwa morfologi dasar laut pada perairan Pulau Kemujan terjadi suatu perubahan kedalaman yang berangsur-angsur bertambah dari garis pantai menuju kelaut lepas. Hal ini sesuai dengan penelitian dari Hediarto et al., (2017) menyatakan bahwa pada perairan Karimunjawa menunjukkan karakteristik morfologi dasar laut nya yakni landai dan bergelombang. Penelitian Sugianto dan Agus (2007) menyebutkan bentuk dari topografi suatu perairan dapat menjadi penyebab dari suatu pola arus perairan tersebut. Pembelokan dari pola suatu arus juga dapat terjadi akibat dari perbedaan dari kedalaman suatu perairan.

Pada bulan September, arah angin cenderung mengarah pada arah timur dan tenggara. Distribusi frekuensi dari klasifikasi angin dominan yakni pada kecepatan angin sebesar 17-21 knots dengan dominasi sebesar 42\% mengarah ke timur dan kecepatan 11-17 knots dengan dominasi sebesar 30\% yang mengarah ke tenggara. Pada bulan Oktober, arah angin juga cenderung dominan mengarah ke timur dan tenggara. Distribusi dari frekuensi dari klasifikasi angin dominan yakni pada kecepatan angin sebesar 11-17 knots dengan dominasi sebesar 34\% mengarah ke timur dan tenggara. Pada bulan November, arah dari angin terlihat sangat dominan mengarah ke timur dan sebagian kecil lainnya mengarah ke tenggara dan barat daya. Distribusi dari frekuensi dari klasifikasi angin dominan yakni pada kecepatan angin sebesar 11-17 knots dengan dominasi sebesar 35\% mengarah ke timur. Hasil pola angin (Windrose) terlihat bahwa pada musim peralihan dua, arah dari pergerakan angin pada setiap bulannya yakni bulan September, Oktober dan November dominan mengarah ke arah timur. Menurut penelitian Najid et al., (2012), Sirkulasi massa air di permukaan perairan Jawa dipengaruhi oleh sistem monsun. Sirkulasi air permukaan pada saat puncak monsun barat laut pada bulan Februari dan puncak monsun tenggara pada bulan Agustus. Sedangkan bulan tengah merupakan bagian dari masa peralihan dari musim barat ke musim timur (September-November) dan musim timur ke musim barat (Maret sampai Mei). Arah angin Laut Jawa mengikuti pola monsun Indonesia, pada musim barat (Desember hingga Februari) dan musim timur (Juni hingga Agustus), angin bertiup lebih cepat dibandingkan musim pancaroba I (Maret hingga Mei) dan II (September hingga November Lintasan utama angin muson berada disepanjang perairan utara Jawa-Madura menyebabkan kondisi hidrooseanografi dan klimatologi yang ada mengikuti pola muson dan sirkulasi massa air (Wyrtki,1961). Penelitian Sugianto dan Agus (2007) menyebutkan disamping dari faktor pasang surut, pola arus juga dapat disebabkan oleh beberapa faktor lain yakni bentuk topografi, perubahan densitas dan pola angin sebagai suatu faktor eksternal. Keadaan musim sangat memiliki peran terhadap pola angin dimana sistem angin monsun memiliki pengaruh terhadap musim panas dan hujan yang berdampak pada variasi dari angin.

Pola arus yang terdapat pada perairan Pulau Kemujan, Karimunjawa cenderung bergerak dua arah ( $b i$ directional) yakni pada arah timur dan barat pada musim peralihan 2 (September - November). Hal ini memiliki kecenderungan yang sama dengan penelitian dari Ismunarti et al.,(2016) yang menyebutkan pola karakteristik arus pada perairan Karimunjawa terkhusus pada perairan Tanjung Batu Lawang, Pulau Kemujan, Karimunjawa cenderung terlihat bahwa pola arus yang bergerak 2 arah (bi-directional current) dan penelitian dari Indrayanti et 
al.,(2021) yang juga menyatakan bahwa pola dari arah arus yang berada pada perairan Pulau Kemujan, Karimunjawa terlihat bertolak belakang (bi-directional).

Pada fase pasang purnama (Spring tide) maupun pasang perbani (Neap tide) dalam bulan September, Oktober dan November memiliki pola arus yang sama yakni pola arus pada kondisi surut dan surut menuju pasang dominan mengarah kearah laut yakni arah barat sedangkan pola arus pada kondisi pasang dan pasang menuju surut dominan mengarah ke arah daratan yakni arah timur. Terlihat bahwa terjadi pembalikan arah $180^{\circ}$ ketika arus pada saat surut menuju pasang dan pasang menuju surut. Penelitian dari Ismanto et al.,(2019) menyatakan bahwa pergerakan pola arus dalam berlawanan arah atau dua arah, dimana arah arus selama pasang yang kebalikan dari arah arus ketika surut arus pasang surut cenderung merupakan sifat dari arus pasang surut dan juga pernyataan dari Ismunarti et al (2016) mengatakan pola dari arus pasang surut umumnya terjadi fase dimana arah arus yang ada mengikuti perubahan ketinggian muka laut, yakni dari fase pasang menuju surut dan pada saat surut menuju pasang. Dari pola arah dan kecepatan arus juga terlihat bahwa terjadi kecenderungan nilai yang fluktuatif dimana mengikuti dari pola pasang surut itu sendiri. Berdasarkan penelitian Thurmann (2007), menyatakan bahwa jika pola arus pada suatu perairan yang bersifat fluktuatif dimana mengikuti dari fluktuatifnya pola pasang surut maka dapat diketahui bahwa arus pasang surut merupakan arus yang dominan pada perairan tersebut. Arus yang terdapat pada perairan Karimunjawa lebih dominan dibangkitkan oleh pasang surut juga dinyatakan pada penelitian-penelitian yang telah dilakukan sebelumnya (Ismunarti et al., 2016; Indrayanti et al.,2020; Indrayanti et al., 2021).

Kecepatan arus yang terdapat pada perairan pulau Kemujan, Karimunjawa pada kondisi pasang purnama (Spring tide) dalam bulan September memilik nilai $0.0505 \mathrm{~m} / \mathrm{s}$, bulan Oktober $0.0526 \mathrm{~m} / \mathrm{s}$ dan bulan November $0.0564 \mathrm{~m} / \mathrm{s}$ dibandingkan dengan kondisi pasang perbani (Neap tide) yakni pada bulan September memiliki nilai $0.0475 \mathrm{~m} / \mathrm{s}$, bulan Oktober $0.0498 \mathrm{~m} / \mathrm{s}$ dan bulan November $0.0523 \mathrm{~m} / \mathrm{s}$. Diketahui bahwa kecepatan rataan yang terdapat pada perairan pulau Kemujan, Karimunjawa pada kondisi pasang purnama (Spring tide) cenderung memiliki nilai yang lebih tinggi dibandingkan kondisi pasang perbani (Neap tide). Penelitian oleh Indrayanti et al., (2021) juga menyatakan bahwa diketahui bahwa arus pada kondisi Spring tide memiliki nilai yang lebih tinggi jika dibandingkan dengan kondisi Neap tide di perairan Kemujan, Karimunjawa. Kondisi ini diakibatkan pada fase pasang purnama (Spring tide), gaya dari pembangkit pasang surut cenderung akan meningkat yang menyebabkan badan air yang bergerak melalui arus jauh lebih tinggi jika dibandingkan kondisi pada fase pasang perbani (Neap tide) yang menyebabkan nilai dari kecepatan arus akan menjadi lebih besar (Surbakti, 2012). Dan juga menurut Prasetyawan et al., (2019) bahwa pada saat terjadi pasang purnama, posisi Bulan-Matahari-Bumi sedang dalam kondisi satu garis lurus, hal ini akan mengakibatkan menguatnya gaya tarik menarik dari gravitasi diantara Bulan-Matahari-Bumi sehingga tinggi muka air akan memiliki gradien yang besar dimana berpengaruh pada kecepatan arus yang juga membesar.

Berdasarkan dari penelitian Indrayanti et al., (2021) mengenai arus pasang surut pada perairan Pulau Kemujan, Karimunjawa menggunakan software Mike 21 didapatkan hasil bahwa pada fase pasang surut pada kondisi purnama (spring tide) diketahui pola arus yang ada merupakan arus bolak balik (bi-directional current)) yang timur laut dan barat daya adalah arah dominannya. Kecepatan arus maksimum yang didapatkan berada pada fase saat surut ke pasang yakni memiliki nilai $13.5 \mathrm{~cm} /$ det dan ketika fase kondisi pasang ke surut dengan nilai sebesar $19.2 \mathrm{~cm} /$ det sedangkan pada penelitian ini yang menggunakan software Delf3D didapatkan juga bahwa terjadi pola arus yang merupakan bi-directional current atau arus yang bolak balik namun dengan arah yang sedikit berbeda yakni dominasi dari pola arus mengarah ke arah barat dan timur. Kecepatan arus maksimum yang didapatkan berada pada saat fase kondisi surut ke pasang yakni memiliki nilai $8,4 \mathrm{~cm} / \mathrm{det}$ dan pada saat fase kondisi pasang ke surut dengan nilai sebesar 7,3 cm/det.

\section{KESIMPULAN}

Pola arus yang terdapat pada perairan pulau Kemujan, Karimunjawa cenderung memiliki pola arah dari arusnya yang bergerak dua arah (bi-directional) dengan arah arus dominan yakni arah barat ketika surut dan arah timur ketika saat pasang. Kecepatan maksimum rata-rata pada kondisi pasang purnama (Spring tide) dalam September memiliki nilai $0.0505 \mathrm{~m} / \mathrm{s}$, Oktober $0.0526 \mathrm{~m} / \mathrm{s}$ dan November $0.0564 \mathrm{~m} / \mathrm{s}$ cenderung memiliki nilai 
yang lebih besar dibandingkan dengan kondisi pasang perbani (Neap tide) yakni pada bulan September memiliki nilai $0.0475 \mathrm{~m} / \mathrm{s}$, bulan Oktober $0.0498 \mathrm{~m} / \mathrm{s}$ dan bulan November $0.0523 \mathrm{~m} / \mathrm{s}$. Hasil penelitian pola arus Perairan Kemujan, Karimunjawa pada musim peralihan II dengan menggunakan model Delft3d menunjukkan verifikasi model yang baik dan sejalan dengan penelitian-penelitian yang telah dilakukan sebelumnya dengan menggunakan model yang berbeda.

\section{DAFTAR PUSTAKA}

BTNKJ (Balai Taman Nasional Karimunjawa). (2017). Statistik Balai Taman Nasional Karimunjawa Tahun 2017.

Deltares. (2011). Functional Specications Delft3D. Deltares, Delft Netherland.

Deltares. (2014). Delft3D-Flow: User Manual. Deltares, Delft Netherland.

Indrayanti, E., D.P. Wijayanti dan H.R. Siagian. (2020). Pasang Surut, Arus Dan Gelombang Berdasarkan Data Pengukuran Acoustic Doppler Current Profiler Di Perairan Pulau Cilik, Karimunjawa. Buletin Oseanografi. 9(1):37-44.

Indrayanti, E., D.N. Sugianto, Purwanto dan H.S. Siagian. (2021) Identifikasi Arus Pasang Surut Di Perairan Kemujan, Karimunjawa Berdasarkan Data Pengukuran Acoustic Doppler Current Profiler. Jurnal Kelautan Tropis, 24(2):247-254.

Ismanto, A., D.H. Ismunarti, D.N Sugianto, S. Maesyarah, P. Subardjo, Suryoputro A.A.D dan H.Siagian. (2019). The Potential Of Ocean Currents Electrical Power Sources Alternatives In Karimunjawa Island Indonesia. ASTES, 4(6):126-133.

Ismunarti, D. H., D.N. Sugianto dan A. Ismanto. (2016). Kajian Karakteristik Arus Laut di Kepulauan Karimunjawa, Jepara. Seminar Nasional Hasil-Hasil Penelitian Perikanan dan Kelautan ke-VI. Universitas Diponegoro. Semarang

Kartawijaya, T., Wibowo, J.T., Ardiwijaya Pardede, S.T., Herdiana, Y., Hidayat A., dan Sudarsono. (2004). Kajian Zonasi Taman Nasional Karimunjawa Bagian dari Proses Untuk Mewujudkan Pengelolaan Bersama, BTNK. Jawa Tengah.

Najid, A., Pariwono, J. I. Bengen, D. G, Nurhakim S., dan Atmadipoera, A. S. (2012). Pola Musiman dan Antar Tahunan Salinitas Permukaan Laut di Perairan Utara Jawa-Madura. Maspari Journal, 4(2), 168-177.

Prasetyawan, I.B., H .Setiyono, Kunarso, Purwanto, Y.J. Wijaya, M.Helmi dan A. Ismanto. (2019). Study Of Ocean Current And Their Effect On Distribution Of Total Suspended Sediment In Coasttal Waters, Semarang. International Journal Of Civil Engineering And Technology (IJCIET), 10(4):248-259.

Septiawan, R.B dan E.Z Astuti. (2016). Perbandingan Metode Setengah Rata-Rata Dan Metode Kuadrat Terkecil Untuk Peramalan Pendapatan Perusahaan Di BLU UPTD Terminal Mangkang Semarang. Techno.COM, 15(2),132-139.

Soewono, E., K.A. Sidarto dan A.K. Supriatna. (2007). Pemodelan dan Simulasi Matematika Pengendalian Epidemi DBD di Wilayah Bandung dan Sekitarnya. Institut Teknologi Bandung 1(1):1-7.

Sontek/YSI. (2006). SonTek/YSI Argonaut Acoustic Doppler Current Meter Technical Documentation. SonTek/YSI, San Diego.

Surbakti, H. (2012). Karakteristik Pasang Surut Dan Pola Arus Di Muara Sungai Musi, Sumatera Selatan. Jurnal Penelitian Sains Universitas Sriwijaya, 15(1):35-39.

Thurmann, H.V., (2007). Introductory Oceanography. Bell and Howell Company Columbus Ohio. p : 183 273.

Yusuf, M., G. Handoyo, Muslim, S. Y. Wulandari dan H. Setiyono (2012). Karakteristik Pola Arus Dalam Kaitannya dengan Kondisi Kualitas Perairan dan Kelimpahan Fitoplankton di Perairan Kawasan Taman Nasional Laut Karimunjawa. Buletin Oseanografi Marina, 1(5), 63-74. http://doi.org/10.14710/buloma.v1i5.6918. 